\title{
Waste-to-biomethane Concept Application: A Case Study of Valmiera City in Latvia
}

\author{
Aiga BARISA*, Ilze DZENE, Marika ROSA, Kristine DOBRAJA \\ Institute of Energy Systems and Environment, Riga Technical University, \\ Azenes iela 12/1, Riga, LV-1048, Latvia
}

\begin{abstract}
The current needs of sustainable urban development are rising. As the transport sector expands, emissions continue to rise. Due to their negative impact on human health and the environment, air quality requirements are becoming more and more stringent. At the same time, the amount of waste is increasing. Europe Union policies attempt to relieve the pressure that these two stressors place on urban systems as they themselves expand. Today different solutions are available to decrease greenhouse gas emissions, increase air quality and improve waste management systems. Among them, waste-to-biomethane for use in urban systems deserves more attention. The paper focuses on application of the concept of waste-to-biomethane and the case study of Valmiera is evaluated. The results show that the application of the waste-to-biomethane strategy can contribute to a complete substitution of diesel fuel in urban buses and gives savings of around $1,000 \mathrm{tCO}_{2} /$ year. The price of the biomethane was found to be the most sensitive input factor. It is suggested that it should not exceed $0.40 \mathrm{EUR} / \mathrm{Nm}^{3}$ for a fuel conversion project of a fleet of 10 vehicles. Such a price can be ensured, if dry fermentation technology is chosen for biogas production. However, from the sustainability perspective, wet fermentation is more preferable due to the introduction of a source-separated organic waste management system in the region and higher gas yields. Introduction of this alternative requires additional funds which is a question of policy-level decisions.
\end{abstract}

Keywords - Biomethane; transport; urban; waste

\section{INTRODUCTION}

In many European regions waste management is still a major problem. Moreover, urban areas often face common issues related to increasing energy consumption and air pollution. In this paper a resource-efficiency idea known as a waste-to-biomethane concept is described. The general framework of the study is shown in Fig. 1. It foresees that organic waste generated in a system is not simply disposed (current practice) but put back into the material cycle and is used to cover energy demand of the system.

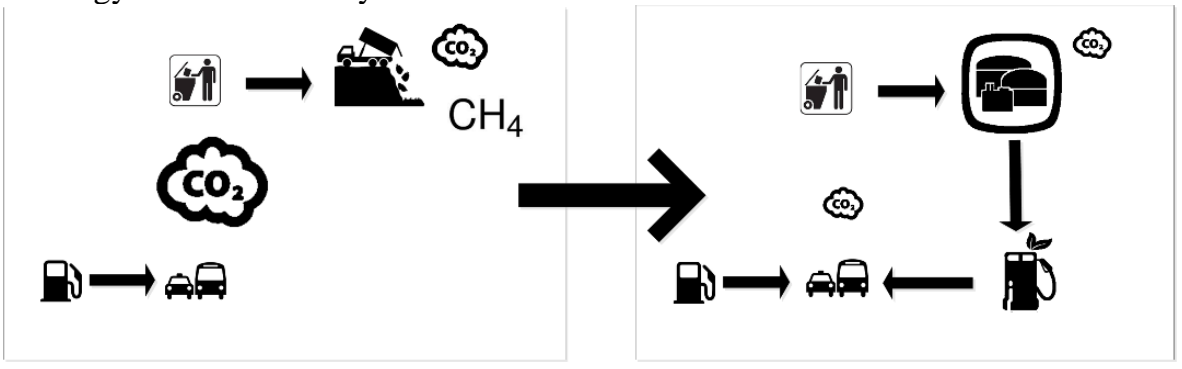

Fig. 1. Integration of biomethane in an urban waste management and transport system.

\footnotetext{
* Corresponding author.

E-mail address: aiga.barisa@rtu.lv
} 
The proposed integration of waste management and energy systems is demonstrated on a case study of Valmiera city in Latvia. Latvia is among the group of countries that landfills over $90 \%$ from the total amount of treated waste. Valmiera was selected as a representative case study because of a common waste management practice and a heavy reliance on fossil fuels for transportation in the city. With around 25,000 inhabitants and an area of $18.2 \mathrm{~km}^{2}$ Valmiera is the largest city in the North Vidzeme region. As a typical mid-sized city in Latvia, this case study ensures a high rate of replicability of the proposed concept in Latvia and other countries. In the European context Valmiera can be considered as small city, however, the importance of small and medium-sized cities should not be underestimated since "they often play a pivotal role within regional economies" [1].

The digestion of biomass to produce biogas is already a mature and commercially available technology. Many research studies suggest anaerobic digestion (AD) as an option for urban municipal solid waste (MSW) management. Curry and Pillary [2] discuss that AD of MSW is one of the most important solutions to solve the increasing waste management problems. Biogas plants using organic MSW can be found in e.g. Germany, Austria and Spain. Recently, Cotana et al. [3] presented the design of a small-sized biogas plant fed by organic waste consisting of garden waste, canteen waste and sewage sludge. Authors suggest that this technology could be a cost-effective solution for a wide variety of collective activities.

Biogas upgrading is one of the alternatives for utilization of biogas. The upgraded biogas can be injected into natural gas grids, used for energy production or to fuel vehicles. An economic evaluation of biomethane production and injection into the natural gas grid in Latvia was performed in [4]. This paper aims to describe a techno-economic feasibility study of biomethane production from MSW generated in a mid-sized city in Latvia and its use for transportation. A detailed explanation of the methodology applied in this study can be found in [5].

\section{Biomethane Potential in Valmiera City AND a Description of Alternatives}

\subsection{Resource Availability}

Valmiera has a simple waste management model and does not have experience with biomethane production or its use. Approximately 12,500 tons of unsorted MSW are generated annually in Valmiera [6] or $500 \mathrm{~kg}$ per capita. Unsorted MSW is delivered to a sorting center that is located next to the landfill site. During the mechanical treatment process, the waste is sorted into several fractions. Around $35 \%$ of the total waste amount is processed into fine fraction and $70 \%$ of it is made of biologically degradable material [7]-[8].

Within the city, the waste management company provides an opportunity for a separate collection of paper, cardboard, glass, plastic, metal and PET waste. Households located in the city boundaries usually do not separate the organic fraction from the main MSW stream. Source separated organic waste collection is provided only for catering companies (canteens, restaurants), food shops (grocery stores, supermarkets) and food processing companies, including food and beverage industries. Separated organic waste is collected from companies in very limited amounts and makes around $100 \mathrm{~m}^{3}$ per year [9]. Most of the organic waste from the food and beverage industry in the area is delivered to farmers for feeding animals or used as fertilizer on agricultural lands. A part of these wastes is delivered to already existing biogas plants that belong to the farmers. Green waste (grass cuttings, tree shavings, fallen leafs etc.) is separately collected in bags or using a crane bucket [7]. According to estimates [9], around 3,000 tons of green waste are collected annually. Another source of organic waste is wastewater 
treatment (WWT) plants. WWT sludge in Valmiera amounted to 1,031 tons in 2012 [10]. The estimated amount of organic waste that is available for biogas production in Valmiera is given in Table 1 (estimations are based on data from 2012).

TABLE 1. ORGANIC WASTE GENERATION IN VALMIERA

\begin{tabular}{lll}
\hline Type of waste & Data source & Amount $(\mathrm{t})$ \\
\hline Organic fraction of the unsorted MSW & Calculated based on [6] & 3,063 \\
Separately collected biowaste from restaurants and grocery stores & {$[9]$} & 50 \\
Separately collected green waste from garden and park management & {$[9]$} & 3,000 \\
WWT sludge (including amount generated by the dairy plant) & {$[10]$} & 1,031 \\
Organic waste from industry (brewer's grain) & {$[11]$} & 10 \\
TOTAL amount of organic waste available for biogas production & - & 7,154 \\
\hline
\end{tabular}

\subsection{Biogas and Biomethane Production Alternatives}

Currently, landfill gas from the site is collected and used to produce electricity in a combined heat and power (CHP) unit. Framework conditions for promoting biomethane production and use in Latvia have not been defined yet. Moreover, the natural gas supply market in Latvia is monopolized until 2017 and there is no legal basis upon which new suppliers can enter the market. Taking into account the existing framework four potential biogas and biomethane production alternatives were analyzed:

- Alternative 1: Dry fermentation + CHP

- Alternative 2: Dry fermentation + CHP until 2020 + biogas upgrading from 2020

- Alternative 3: Wet fermentation + CHP

- Alternative 4: Wet fermentation + CHP until 2020 + biogas upgrading from 2020.

Alternatives 1 and 3 assume that the current landfill gas collection and electricity generation in the CHP plant is supplemented by a new anaerobic digestion (AD) unit for biologic MSW treatment. In Alternative 1, the AD unit uses dry fermentation technology. In Alternative 3, the $\mathrm{AD}$ unit uses wet fermentation technology. Further, alternatives 2 and 4 assume that both previously described scenarios are supplemented with a biogas upgrading plant using pressure swing adsorption technology. In these scenarios the CHP unit is in operation by 2020, afterwards being replaced by the biogas upgrading plant.

Input in the analysis were the capital cost of biogas production technology and biogas upgrading technology, the annual operation and maintenance costs (including feedstock costs) and expected revenues (e.g., sales of biomethane, electricity feed-in tariff, subsidies, waste collection fees, etc.). The cash flow analysis was performed to evaluate the expected internal rate of return (IRR) and the net present value (NPV) of each alternative. It also gave the opportunity to determine sensitive criteria that affects the economic performance of the solution. Moreover, it allowed to assess the optimal price of the biomethane for the project to be economically feasible or to what extent additional subsidies would be needed to keep the biomethane production price at a certain level.

\section{SCENARio RESUlts}

\subsection{Biogas and Biomethane Production Alternatives}

In Fig. 2, the calculated available amount of biogas and biomethane in Valmiera is presented by 2030. Around $1.1-1.5$ million $\mathrm{Nm}^{3}$ of biogas and $608-862$ thousands $\mathrm{Nm}^{3}$ of biomethane could be produced annually from MSW generated in the target region starting from 2020 depending on the technology chosen. The sharp increase in gas production in Fig. 2 corresponds 
to the introduction of the $\mathrm{AD}$ unit in addition to the existing landfill gas collection. The time delay between the two scenarios is due to the necessity of introducing a source separated by the waste collection system in the Wet fermentation scenario. The production rate of biogas is decreases gradually by 2024 in response to reduced gas yield from the wells. However, the production starts increasing again afterwards because more organic waste will be generated from growing population and economic activity in the region.

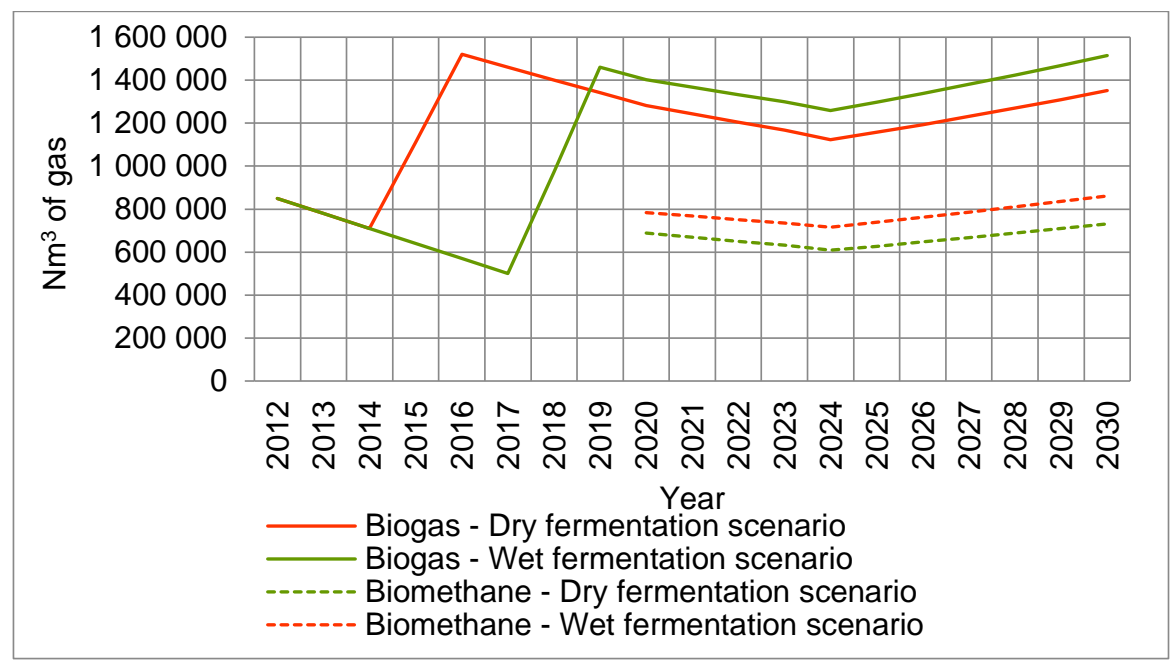

Fig. 2. Biogas and biomethane production potential in Valmiera.

Economic viability of the proposed biogas and biomethane production alternatives is compared in Table 2.

TABLE 2. COMPARISON OF BIOGAS AND BiOMETHANE PRODUCTION ALternativeS

\begin{tabular}{|c|c|c|c|c|}
\hline Parameter & Alternative 1 & Alternative 2 & Alternative 3 & Alternative 4 \\
\hline $\begin{array}{l}\text { Minimal price of the } \\
\text { biomethane, EUR/ } \mathrm{Nm}^{3}\end{array}$ & No biomethane & 0.35 & No biomethane & $0.74(0.35)$ \\
\hline $\begin{array}{l}\text { Subsidy needed (to reach } \\
\text { IRR }=7 \% \text { ) }\end{array}$ & $\begin{array}{l}\text { Not needed } \\
(\text { IRR }=26 \%)\end{array}$ & Not needed & $\begin{array}{l}71 \% \text { of } \\
\text { investment costs } \\
\text { or increase of } \\
\text { waste tariff by } \\
1.88 \mathrm{EUR} / \mathrm{m}^{3}\end{array}$ & $\begin{array}{l}\text { Not needed }(63 \% \\
\text { of investment } \\
\text { costs or increase } \\
\text { of waste tariff by } \\
1.66 \mathrm{EUR} / \mathrm{m}^{3)}\end{array}$ \\
\hline
\end{tabular}

Alternative 1: Dry fermentation + CHP; Alternative 2: Dry fermentation + CHP (until 2020) + biogas upgrading (from 2020); Alternative 3: Wet fermentation + CHP; Alternative 4: Wet fermentation + CHP (until 2020) + biogas upgrading (from 2020).

In case the existing landfill gas collection is supplemented with a new AD plant based on the dry fermentation technology (Alternative 1), the IRR is $26 \%$; however, this alternative does not foresee the production of biomethane. For the second alternative with dry fermentation technology and biomethane production starting from 2020, in order to get the cash flow positive, the revenues from selling biomethane should be at least $0.35 \mathrm{EUR} / \mathrm{Nm}^{3}$. In case the dry fermentation unit is replaced by the wet fermentation technology, economic viability of the project drops in return to increased capital costs compared to the dry fermentation scenario. For the third alternative (landfill gas collection in combination with wet fermentation, but without biomethane production) in order to have the project IRR equal to $7 \%$, at least $71 \%$ of the 
investment costs must be covered by a subsidy or the existing waste management tariff must be increased by $1.88 \mathrm{EUR} / \mathrm{m}^{3}$. For the last scenario (wet fermentation and biogas upgrading) in order to get a positive cash flow, the revenues from biomethane sales should be at least 0.74 EUR/ $/ \mathrm{Nm}^{3}$. If the biomethane sale price is equal to the price given in Alternative $2(0.35$ EUR/ $/ \mathrm{Nm}^{3}$ ), then the investment cost subsidy or additional revenues from the waste management tariff are needed.

The results were further used to analyze the potential biomethane utilization routes.

\section{2. $\quad$ Biomethane Utilization Alternatives}

In order to compare the use of biomethane in transport with other alternatives, a simplified evaluation of environmental performance (in terms of $\mathrm{CO}_{2}$ emission savings) of each alternative was done. Results are shown in Table 3.

\section{TABle 3. Results of the Three Alternative Ways of USING BIOGAS/BIOMETHANE IN VALMIERA}

\begin{tabular}{lll}
\hline Parameter & Dry fermentation & Wet fermentation \\
\hline Production of biogas, mil. $\mathrm{Nm}^{3} /$ year & 1.2 & 1.3 \\
1. Electricity generation in $\mathrm{CHP}$ & & \\
Electricity production, $\mathrm{MWh} / \mathrm{year}$ & 2,382 & 2,781 \\
$\mathrm{CO}_{2}$ emissions reduced, $\mathrm{tCO} /$ year & 206 & 303 \\
$\quad$ Production of biomethane, $\mathrm{Nm}^{3} / \mathrm{year}$ & 665,482 & 777,125 \\
2. Biomethane use in transport & & \\
Replacement of diesel, liter & 571,850 & 667,785 \\
$\mathrm{CO}_{2}$ emissions reduced, $\mathrm{tCO}_{2} /$ year & 1,507 & 1,760 \\
3. Grid injection & & \\
$\mathrm{Natural}_{\text {gas replaced, } \mathrm{MWh} \text { of fuel }}$ & 6,655 & 7,771 \\
$\mathrm{CO}_{2}$ emissions reduced, $\mathrm{CCO}_{2} /$ year & 1,344 & 1,570 \\
\hline
\end{tabular}

The results show that the highest $\mathrm{CO}_{2}$ emission savings can be achieved in case biomethane is used to substitute diesel fuel for transportation. Further two alternative scenarios for biomethane utilization in the transport sector were developed and a techno-economic analysis was performed. The results are described in Sections 3.2.1. and 3.2.2. In Section 3.3. a comparison of both alternatives is given.

The first scenario offers to use the biomethane in waste collection trucks. Currently all MSW in Valmiera is collected by a single waste management company which is responsible for MSW collection and treatment in the North Vidzeme region. The company currently operates 25 refuse trucks running on diesel. Annual diesel consumption is around 500,000 liters and the annual fuel costs are around 640,000 EUR. Based on daily mileage statistics it was estimated that 10 refuse trucks would be suitable for the fuel conversion project. Such mileage would allow filling once per day, which would be an appropriate solution for the company.

The second alternative offers to use the biomethane in Valmiera city buses. A company coowned by the city administration, operates 10 bus routes on a daily basis. Annual diesel consumption for the public fleet is around 276,000 liters. Average mileage of a city bus is 135 $\mathrm{km}$ per day. Regional bus routes operated by the company go outside the city borders within a distance of $200 \mathrm{~km}$.

Comparison of both alternatives was based on:

1) Evaluation of the technical potential including such criteria as the number of vehicles to be converted, average mileage (km/day), fuel consumption (liter of diesel or $\mathrm{Nm}^{3}$ of biomethane per $100 \mathrm{~km}$ ), engine efficiency, and; 
2) Evaluation of the economic potential considering investment and O\&M costs related to biomethane introduction in the vehicle fleet.

The main data used in the methodology for the case study are summarized in the Table 4. A cash flow analysis was performed in order to evaluate the expected IRR of each alternative. The following additional assumptions were made:

- Project lifetime: 10 years;

- Inflation: $3 \% /$ year;

- O\&M costs: $5 \%$ of capital costs. Salary costs and electricity costs correspond to Latvian conditions;

- Debt capital: $75 \%$, equity capital: $25 \%$. Annual interest rate: $6 \%$, and;

- Biomethane price in the Dry fermentation scenario: 0.35 EUR/ $\mathrm{Nm}^{3}$ [11], biomethane price in the Wet fermentation scenario: 0.35 EUR/ $\mathrm{Nm}^{3}$ [11].

\section{TABle 4. BAseline Scenario Assumptions (CBG - Compressed Biogas/ Biomethane)}

\begin{tabular}{lll}
\hline & Waste collection trucks & Public busses \\
\hline Number of vehicles to be converted to CBG & 10 & 10 \\
Average daily distance of a vehicle, km/day & 140 & 135 \\
Average fuel consumption of a vehicle, $1 / 100 \mathrm{~km}$ & 40 & 40 \\
Type of fuel & Diesel & Diesel \\
Number of fleet-owned fueling stations & 1 & 1 \\
Incremental investment costs of a CBG vehicle, thousand EUR/vehicle & 30 & 23 \\
Fueling station cost, thousand EUR & 600 & 600 \\
Initial diesel price (EUR/l) & 1.53 & 1.53 \\
\hline
\end{tabular}

\subsubsection{Alternative 1: Biomethane application in waste collection trucks}

In the Dry fermentation scenario, the suggested price of biomethane is $0.35 \mathrm{EUR} / \mathrm{Nm}^{3}$. In this case a 10 vehicle fleet is converted from diesel to compressed biomethane gas (CBG), the IRR of the project is $16 \%$. Considering the available amount of biomethane, the maximum size of a fleet is 21 vehicles. In such case, the IRR of the project increases threefold and is $66 \%$.

In the Wet fermentation scenario, the suggested price of biomethane should be at least $0.74 \mathrm{EUR} / \mathrm{Nm}^{3}$. The results show that, based on initial assumptions, if the 10 vehicle fleet is converted from diesel to $\mathrm{CBG}$ and there are no financial support incentives for vehicle purchase or installation of a filling station, the IRR of the project is negative. There are several alternatives how to improve the feasibility of the project. The first scenario suggests there is state assistance for covering the price premium of $\mathrm{CBG}$ vehicles or costs related to installation of a filling station. However, results show that in case of a 10 vehicle fleet, even external financing sources will not ensure a positive cash flow. The second scenario suggests that the initial 10 vehicle fleet is increased. However, results show that even converting all the company's vehicle fleet (25 refuse trucks) will not ensure a positive IRR without some sort of subsidy. Moreover, the size of the convertible vehicle fleet is restricted due to a limited amount of biomethane. In the wet fermentation scenario, a total of 24 vehicles could be converted from diesel to biomethane. A $7 \%$ IRR can be achieved in case 24 refuse trucks are converted with a $40 \%$ subsidy for vehicle price premium coverage and a $20 \%$ subsidy for filling station.

Alternatively, if the price of biomethane is lower than $0.74 \mathrm{EUR} / \mathrm{Nm}^{3}$ in the Wet fermentation scenario (e.g., if subsidy is provided to lower capital costs), the IRR of the project can be improved. Thus, if the price of biomethane is equal to the one in the Dry fermentation scenario $\left(0.35 \mathrm{EUR} / \mathrm{Nm}^{3}\right)$, IRR of a 10 vehicle fleet project is $36 \%$ and IRR of a 24 vehicle project is $74 \%$. It is suggested that the price of biomethane should not be higher than $0.40 \mathrm{EUR} / \mathrm{Nm}^{3}$ in order for a 10 vehicle fleet to have an acceptable IRR $=7 \%$ without any external funding. It is 
suggested that the price of biomethane should not be higher than $0.63 \mathrm{EUR} / \mathrm{Nm}^{3}$ in order for a 20 vehicle fleet to have an acceptable IRR $=7 \%$ without any external funding.

\subsubsection{Alternative 1: Biomethane application in public transport buses}

In the Dry fermentation scenario (biomethane price $0.35 \mathrm{EUR} / \mathrm{Nm}^{3}$ ), conversion from diesel to CBG is economically viable already in a fleet of 10 vehicles (IRR $=19 \%$ ). With the available amount of biomethane, the maximum fleet of 21 buses can be converted. In such case, the IRR of the project increases notably and is $77 \%$.

In the Wet fermentation scenario, with the suggested price of biomethane $0.74 \mathrm{EUR} / \mathrm{Nm}^{3}$, the IRR of a 10 bus project is negative. In order to achieve a positive IRR, there are several options. Results indicate that similarly as in the case of waste collection trucks, only high rates of cofunding (exceeding a $90 \%$ funding covering price premium of vehicle purchase and installation of a filling station) are sufficient to ensure a positive cash flow of the project. Increasing the number of vehicles in the fleet to be converted increases the IRR of the project. Thus this alternative becomes feasible in the case where both intercity and regional city buses are included in the project. The maximum number of buses to be converted to biomethane is 25 considering the fuel resource limitation. In case 25 buses are converted from diesel to biomethane and considering a $20 \%$ subsidy is provided to cover vehicle price premium in combination with a $10 \%$ subsidy for the filling station, a $7 \%$ IRR is projected These results are mainly affected by the biomethane price which is assumed to be $0.74 \mathrm{EUR} / \mathrm{Nm}^{3}$ (with a $3 \%$ annual increase).

\subsection{Comparison of Biomethane Transport Application Alternatives}

A comparison of the alternatives is presented in Tables 5 and 6. In Table 5, alternatives are compared in case of a 10 vehicle fleet (reference scenario considering specifics of the case study). Results show that without external funding, i.e. investment cost subsidies or additional revenue from the waste management tariff, only the Dry fermentation scenario is able to achieve a positive cash flow. The fundamental factor underlying this result is the price of the biomethane. With biomethane price $0.35 \mathrm{EUR} / \mathrm{Nm}^{3}$, replacement of diesel to biomethane as the transport fuel is a viable solution already in a 10 vehicle fleet. If the price of the biomethane is twice as high (as suggested in the Wet fermentation scenario), viability of the 10 vehicle project drops significantly. However, biogas production in wet fermentation results in higher gas yields and therefore more fossil fuel can be substituted. Moreover, wet fermentation is a more sustainable solution in the longer-term since it includes the establishment of a separated waste collection system in the urban area.

TABLE 5. COMPARISON OF BIOMETHANE TRANSPORT ALTERNATIVES IN THE REFERENCE SCENARIO (10 VEHICLE FLEET)

\begin{tabular}{lllll}
\hline & $\mathrm{A} 1-$ Trucks & $\mathrm{A} 1-$ Buses & $\mathrm{A} 2-$ Trucks & A2 - Buses \\
\hline Number of vehicles & 10 & 10 & 10 & 10 \\
\hline Price of the biomethane, EUR/Nm ${ }^{3}$ & 0.35 & 0.35 & 0.74 & 0.74 \\
\hline Investment costs, thousand EUR & 900 & 830 & 900 & 830 \\
\hline Annual fuel cost savings, thousand EUR/year & 242.6 & 233.9 & 107.6 & 103.7 \\
\hline Annual $\mathrm{CO}_{2}$ savings, tons $\mathrm{CO}_{2} /$ year & 540 & 520 & 540 & 520 \\
\hline IRR & $16 \%$ & $19 \%$ & Negative & Negative \\
\hline Subsidy needed (IRR=7 \%), EUR & Not needed & Not needed & $>90 \%$ & $>90 \%$ \\
\hline
\end{tabular}

A1 - Mechanical waste treatment and following biogas production in dry fermentation; A2 - Source separated waste collection and following biogas production in wet fermentation 
In Table 6, alternatives are compared in case of maximum vehicle fleet that can be converted to $\mathrm{CBG}$ considering the availability of biomethane in the target region. This scenario was included in the study to see, what influence does the size of vehicle fleet has on project economics. This scenario is also a representative evaluation for urban areas larger than the specific case study of Valmiera city. The results show that increasing the number of vehicle fleet from the initial 10 vehicles to 21-25 (depending on the scenario), increases the economic viability of the conversion project. However, the Wet fermentation scenario is still represented by a negative 10-year cash flow, if no subsidies are included. The best environmental performance is, however, associated exactly with the Wet fermentation scenario. Both in terms of absolute $\mathrm{CO}_{2}$ emission savings ( $\mathrm{t} \mathrm{CO}_{2}$ per year) and specific $\mathrm{CO}_{2}$ emission savings (accumulated $\mathrm{tCO}_{2}$ per EUR invested), the Wet fermentation scenario with biomethane utilization in the bus fleet shows the best results.

TABLE 6. COMPARISON OF BIOMETHANE TRANSPORT ALTERNATIVES IN THE MAXIMUM UTILIZATION SCENARIO (21-25 VEHICLE FLEET)

\begin{tabular}{|c|c|c|c|c|}
\hline & \multicolumn{4}{|c|}{ Alternative } \\
\hline & A1 - Trucks & A1 - Buses & A2 - Trucks & A2-Buses \\
\hline Number of vehicles & 21 & 21 & 24 & 25 \\
\hline Price of the biomethane, EUR/Nm ${ }^{3}$ & 0.35 & 0.35 & 0.74 & 0.74 \\
\hline Investment costs, thousand EUR & 1,230 & 1,083 & 1,320 & 1,175 \\
\hline $\begin{array}{l}\text { Annual fuel cost savings, thousand } \\
\text { EUR/year }\end{array}$ & 509.4 & 491.2 & 258.1 & 259.3 \\
\hline Annual $\mathrm{CO}_{2}$ savings, tons $\mathrm{CO}_{2} /$ year & 1,131 & 1,091 & 1,293 & 1,299 \\
\hline IRR & $66 \%$ & $77 \%$ & $\begin{array}{l}\text { Negative } \\
40 \% \text { vehicle }\end{array}$ & $\begin{array}{l}\text { Negative } \\
20 \% \text { vehicle }\end{array}$ \\
\hline Subsidy needed (IRR=7 \%), EUR & Not needed & Not needed & $\begin{array}{l}\text { incremental costs + } \\
20 \% \text { filling station }\end{array}$ & $\begin{array}{l}\text { incremental costs + } \\
10 \% \text { filling station }\end{array}$ \\
\hline
\end{tabular}

A1 - Mechanical waste treatment and following biogas production in dry fermentation; A2 - Source separated waste collection and following biogas production in wet fermentation

\section{DISCUSSION AND CONCLUSION}

In this study, a techno-economic analysis of biomethane production and consumption alternatives from organic municipal waste was performed based on a case study of Valmiera city in Latvia.

The amount of biogas and biomethane depends on selected technologies throughout the whole value chain. The wet fermentation scenario gives a higher biomethane output, however the costs related to the introduction of source separated organic waste collection for households and investment costs in wet anaerobic digestion plant are higher. Therefore, an investment cost subsidy or increase of the waste tariff should be provided. Of the biogas and biomethane production alternatives, only the dry fermentation technology (Alternatives 1-2) showed to be economically viable without any additional funding. In case of biogas production with dry fermentation technology and following upgrading, the price of biomethane should be at least $0.35 \mathrm{EUR} / \mathrm{Nm}^{3}$ to have a positive project cash flow. This price is 1.5 times lower than the price of natural gas in Latvia (for transport applications), and three times lower than the price of conventional transport fuels. Thus, biogas production in dry fermentation becomes more preferable from the end-user point of view.

The second part of the feasibility study, which analyzed two alternatives of biomethane utilization, confirmed that the price of biomethane is a highly sensitive factor. The price of biomethane should not exceed $0.40 \mathrm{EUR} / \mathrm{Nm}^{3}$ for a 10 vehicle fleet to have an acceptable internal rate of return (IRR $=7 \%$ ). If the price of biomethane exceeds this value, conversion 
projects lose their economic viability and need to have partly covered investment costs. This is the case of the wet fermentation scenario where higher investment costs result in a higher minimum acceptable biomethane price $\left(0.74 \mathrm{EUR} / \mathrm{Nm}^{3}\right)$. On the other hand, from a long-term sustainability perspective, introduction of the wet fermentation technology would be more beneficial since it goes hand in hand with introduction of a source-separated organic MSW collection system in the city. Moreover, the wet fermentation technology allows producing more biogas compared to the dry fermentation technology. Thus, currently used fossil fuels can be replaced to a greater extent.

1,091-1,299 tons of $\mathrm{CO}_{2}$ emissions can be saved annually by replacing the currently used diesel fuel in the studied region. Achieved $\mathrm{CO}_{2}$ emission savings are dependent on the available amount of biomethane and the demand of biomethane, i.e. the size of the vehicle fleet. Authors intentionally restricted analysis of the application of the biomethane for public needs, i.e. in public transport and waste collection trucks. The main purpose was to estimate contribution required from the municipality if the waste-to-biomethane concept is implemented only by a municipality. However, there are other options, e.g. involvement of private actors, selling of biomethane in public refilling stations that would lead to higher IRR and NPV of the case study, but it was out of the scope of this study.

The results show that upgrading biogas to biomethane and using it in transport is an opportunity for efficient use of renewable energy in urban areas. E.g., application of the wasteto-biomethane strategy in the described case study may result in complete substitution of diesel used in public transport or in waste collection trucks in the city. This approach meets European Union targets in the fields of waste management, greenhouse gas emission savings and renewable energy [12]-[14]. Moreover, biomethane use in transport could contribute to meeting the $10 \%$ renewable transport energy target in Latvia by 2020 which has been previously discussed by Barisa and Rosa [15].

\section{ACKNOWLEDGEMENT}

This work was supported by the Nordic Energy Research 'Technology Opportunities in Nordic Energy System Transitions' (TOP-NEST) project and is using results of the study performed in the UrbanBiogas project. The UrbanBiogas project (Contract No.IEE/10/251) is funded by the European Commission under the Intelligent Energy Europe program.

\section{REFERENCES}

[1] European Commission, 2011. Cities of tomorrow - Challenges, visions, ways forward. Luxembourg: Publications Office of the European Union, 112 p.

[2] Curry N., Pillay P. Biogas prediction and design of a food waste to energy system for the urban environment. Renewable Energy 2012:41:200-209. doi:10.1016/j.renene.2011.10.019

[3] Cotana F., Petrozzi A., Cavalaglio G., Coccia V., Pisello A. L., Bonamente E. A batch digester plant for biogas production and energy enhancement of organic residues from collective activities. Energy Procedia 2014:61:1669 1672. doi:10.1016/j.egypro.2014.12.188

[4] Paturska A., Repele M., Bazbauers G. Economic assessment of biomethane supply system based on natural gas infrastructure. Energy Procedia 2015:72:71-78. doi:10.1016/j.egypro.2015.06.011

[5] Dzene I., Barisa A., Rosa M., Dobraja K. A conceptual methodology for waste-to-biomethane implementation in an urban environment, International Scientific Conference of Environmental and Climate Technologies - CONECT 2015, 14-16th October, Riga, Latvia.

[6] Latvian Environment, Geology and Meteorology Centre (LVGMC), 2014. Statistics on Waste Generation „3Atrkitumi" [Online]. Available: http://parissrv.lvgmc.lv/\#viewType=wasteatvkproducer\&incrementCounter=4

[7] North Vidzeme Waste Management Company (ZAAO), 2013. North Vidzeme Regional Waste Management Development Plan 2014-2020 [Online]. Available: http://www.zaao.lv/upload/File/ZV\%20RAAP 01042013 projekts.pdf 
[8] Arina D. Characteristics of Mechanically Sorted Municipal Wastes and Their Suitability for Production of Refuse Derived Fuel. Environmental and Climate Technologies 2012:8:18-23.

[9] North Vidzeme Waste Management Company (ZAAO), 2012. Waste management concept for Valmiera. Urbanbiogas project (No: IEE/10/251) report [Online]. Available: http://www.urbanbiogas.eu/images/pdf/ IR/ANNEX_IR_10_D3_3_ZAAO_EN_WasteConcept.pdf

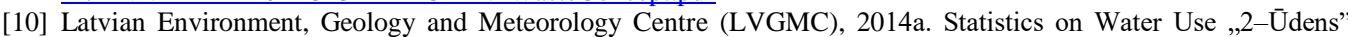
[Online]. Available: http://parissrv.lvgmc.lv/\#viewType=sludgeproductiontercoarse\&incrementCounter=2

[11] Dzene I., Slotina L., Drukmane L. Biogas \& Biomethane production in Valmiera, Latvia. Urbanbiogas project (No: IEE/10/251) report [Online]. Available: http://www.urbanbiogas.eu/images/pdf/2PR/ANNEX_2_17_D4_3 EKODOMA_Biogas-Concept-Valmiera.pdf

[12] Directive 2008/98/EC of the European Parliament and of the Council of 19 November 2008 on waste and repealing certain Directives. Official Journal of the European Union 2008:L312:3-30.

[13] Directive 2009/28/EC of the European Parliament and of the Council of 23 April 2009 on the promotion of the use of energy from renewable sources and amending and subsequently repealing Directives 2001/77/EC and 2003/30/EC. Official Journal of the European Union 2009:L140:16-62.

[14] Decision No 406/2009/EC of the European Parliament and of the Council of 23 April 2009 on the effort of Member States to reduce their greenhouse gas emissions to meet the Community's greenhouse gas emission reduction commitments up to 2020. Official Journal of the European Union 2009:L140:136-148.

[15] Barisa A., Rosa M. Modelling transition policy to a sustainable regional transport system: A case study of the Baltic States. Management of Environmental Quality 2015:26:357-372. doi:10.1108/MEQ-08-2014-0122
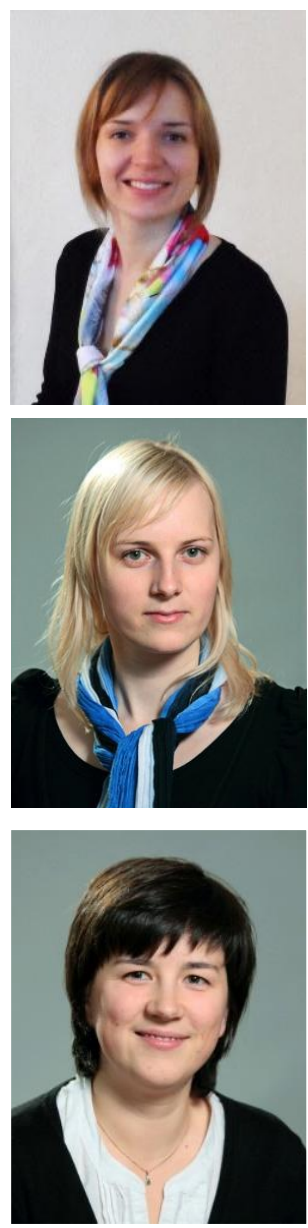

Aiga Barisa, M. sc., Riga Technical University, Institute of Energy Systems and Environment. Aiga acquired Bachelor's degree in Environmental Science in 2010 and Master's degree in 2012. Both bachelor and master theses were dedicated to promotion of renewable energy sources in Latvian district heating systems. She has working experience as a Scientific Assistant in Riga Technical University and as a Project Assistant in engineer consulting company. Currently she is a PhD student at Institute of Energy Systems and Environment. The main research area is renewable energy sources.

Ilze Dzene, Dr. sc. ing., has a diploma in computer science and information technology (2003), master of science degrees in information technology (2005) and environmental science (2007). She has obtained a doctor degree in environmental engineering in 2011. She works in the Riga Technical University, Institute of Energy Systems and Environment from the year 2005, and currently is docent and researcher. Ilze Dzene is also working as a Project Manager for the energy consulting company Ekodoma. Her main research interests are related to sustainable energy planning, integration of renewable energy sources in energy systems, biogas and efficiency of biogas plants. Ilze Dzene is a member of the Latvian Biogas Association.

Marika Rosa, Dr. sc. ing., asoc.proffesor, Riga Technical University, Institute of Energy Systems and Environment. Marika Rochas has been part of academic staff of Faculty of Energy and Electronics, Riga Technical University since 2003. The main research area are cleaner production and energy efficiency. She has participated in different local and international projects related to energy and environment. Her $\mathrm{PhD}$ thesis "Analysis of mechanisms for $\mathrm{CO}_{2}$ emission reduction in Latvian energy installations" was defended in Faculty of Power and Electrical Engineering, Riga Technical University (2006). 


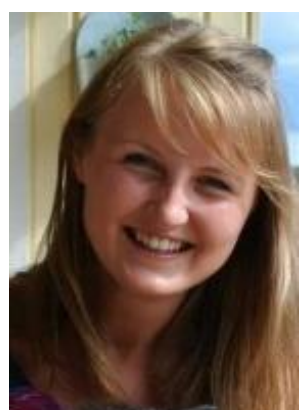

Kristine Dobraja, M. sc., Riga Technical University, Institute of Energy Systems and Environment. She acquired Bachelor's degree in Environmental Science in 2013 and her Master's degree in Environmental Science in 2015. Kristine is a member of the "Association of Latvian Environmental Science Students". 